\title{
Analysis of precipitation in Belém-PA city (period 1967-2016)
}

\begin{abstract}
The objective of the study was to analyze the precipitation behavior in the city of Belém do Pará ( $1^{\text {st }} 49^{\prime}$ S and $\left.48^{\circ} 49^{\prime} \mathrm{W}\right)$, between $01 / 01 / 1967$ and $12 / 31 / 2016$, the daily data of the National Institute of Meteorology (INMET), are grouped by decades, years and months, to identify the largest and smallest rainfall in the period. Using the percentile technique, events with an upper value of $63 \mathrm{~mm}$, considering k-eximo of 0.99 , were separated, defining a limit for the study of extreme events and verifying the variation during the period. The results showed a tendency of growth of the amount of average precipitation in the last five decades; however, in the last decade it presents a significant drop, where the precipitation reached $16.9 \mathrm{~mm}$. Previous studies indicate that these variations in the precipitation of the city of Belém (PA) are little influenced by the phenomenon of Niño (EN and LN). Concluding that the Intercropical Convergence Zone (ICCIT) and the Instability Line (LS) are the main modulators of precipitation in Belém (PA). The precipitation behavior is similar to the parameters: Southern oscillation index (IOS), quasi-benial oscillation (OQB) and CIIFEN Atlantic Thermal Index (ITA), which refer to global climate change conditions.
\end{abstract}

Keywords: urban climate, el niño, la niña, ZCIT
Volume 2 Issue 3 - 2018

\section{Ronaldo Rosales Mendoza, Mota MAS}

Department of Environmental Sciences, Federal University of Pará, Brazil

Correspondence: Ronaldo Rosales Mendoza, Department of Environmental Sciences, Federal University of Pará, Brazil, Email ambientalge@gmail.com

Received: February 21, 2018 | Published: May II, 2018

\section{Introduction}

The world's climatic conditions are diverse; in addition, populations and economies evolve according to the limits of vegetation distribution, rainfall and temperature. Köppen in 1918 classified the planet in bio-climatic zones, with names: tropical rainy, subtropical, temperate rainy, cold and polar forest (KOTTEK et al., 2006). Thanks to each bio-climatic zone, ecosystems contribute goods and services to mankind, which allow the existence of a very large biodiversity, thus allowing man to satisfy his needs. ${ }^{1}$ To this respect, Morris (2012) mentions that, historically, man has preferred to develop his activities near the rivers, because it is where he finds easy access to water for consumption and hygiene, mainly. However, the climatic conditions in the last decades have presented adverse situations for the humanity. In the records available in the international disaster database, Emergency Events Database (EM-DAT) show that events related to climatology, meteorology and hydrology have changed generating concern worldwide, mainly related to human and economic losses. Then, in the relationship between man and water resources, the water resource in the same way as an ally can become a "hazard", a hazard is defined as: "the risk of an uncertain and uncertain relationship that may affect or even affect upsetting a population in their environment, in the routine or way of life, "These hazards are not only natural has a population-environment relationship, observed thus, by the Engineers of the United States of America in 1993, when presenting the construction of dams, irrigation and navigation systems as solutions to flood problems, proposals that still leave important gaps. ${ }^{2}$

Risks have been studied including different perspectives, such as hydrology, climate change, extreme events, and vulnerability. Grosso (2010) mentions that there is a need to articulate a set of actions aimed at reducing risks in urban areas, associated with support and prevention systems, in order to assist municipal management activities, in accordance with the urbanization programs of areas more vulnerable and with low infrastructure. These observations are the basis for generating research actions and directing economic resources, and tackling climate change with increasing population. ${ }^{3}$ For management in water management and environmental management are interrelated activities and can affect institutional arrangements inserted in one or other practice, including in management the collection by the use of both waters and soil. ${ }^{4}$ Using information from eight South American countries, ${ }^{5}$ present sustainable solutions to a problem that generates many losses in society, such as floods. They also indicate that the development of land use (urbanization) is a key factor in impacts on water systems and urban water management. And there are different interactions between the mechanisms of supply, sanitary sewage, urban drainage and river floods and solid waste, in addition to waterborne diseases. In this way, the management of water resources must be conducted in a systemic way, in order to guarantee the supply of water in sufficient quantity and quality to meet the needs of society. ${ }^{1}$ Therefore, the interactions between human interventions and the natural environment within river basins must be considered. For water, besides representing an essential resource for life and human society is also a common denominator in any analysis and evaluation of the environment and the natural, terrestrial and aquatic resources of a region. ${ }^{6}$ Therefore, these conditions force the evolution of policies and laws to manage these resources, considering also that human actions have consequences. These actions overlap borders, so it is important to build international dialogue that overcomes fragmentation, complex systems, scale disagreement, uncertainty, spaces and climate change.?

Climate change is the result of several factors, including anthropogenic actions. In the anthropogenic actions, the man when making use of the natural resources ends up polluting the air, rivers and oceans generates a series of diseases the population. Natural factors are the inclination of the Earth's axis relative to the Sun and its orbit, the distribution of the continents, the availability of sources of moisture, relief, vegetation, and animal species. So it is important to know the relationship between the factors and try to find 
proposals that help in the coexistence of Man-Nature, coexistence called "adaptation". ${ }^{89}$ Adaptation to climate change is approached from different perspectives, both from natural conditions and from population development. However, they present difficulties of understanding and understanding among professionals, scientists, researchers, and especially the population. With different positions the discourse on climate change and the socioeconomic problem. ${ }^{10,11}$

The city of Belém do Pará was selected for the study because of the availability of data and ease of observation of events occurring in the city. The city of Belém was born from a privileged position at the entrance of the Amazon, initially exploited by military strategy and timely trade. The Ver-o-Peso market is an icon because it has prospered the mercantilism and development of the city. The commercialization of rubber in the period 1850-1920 gave rise to several improvements in infrastructure, the most significant of electric light, with the decline of Brazilian rubber to the detriment of Malaysian rubber, the economy declined. Other interventions in the infrastructure of the city of Belém, such as the improvement of the Boulevard da Republic, the implementation of a US naval base in exchange for the levee system to level and mitigate the effects of the tides, basic sanitation and construction of the Belém-Brasília highway was a product of its role in the international context. ${ }^{12}$

Nowadays, the city full of vertical condominium buildings grows both in population and in infrastructure, where new and remodeled buildings intend to harmonize and compete in the local market. The growth and development of the population brought favorable conditions both for the growth of the vehicular fleet and for problems of sanitation, coexistence, security, health, etc., typical of the great cities of the world. The change in the use of soil proves the registration of a reduction of the vegetal cover, caused mainly by the advance of the human occupation, that contributes to intensify the formation of heat islands in the occupied areas this increase of the temperature allied to the stopped water favors the proliferation of vectors of parasitic diseases. ${ }^{13,14}$ The infrastructure works thought to be insufficient before the reality, complicating the response of social attention, medical, and work. All this results in an operational chaos, which coexists with natural climatic conditions such as precipitation that constantly threaten the population, with floods and other problems observed by the World Water Assessment Program. ${ }^{15}$ For example, Santos, ${ }^{13}$ Dos Santos \& ROCHA ${ }^{14}$ show that the basin of the Quintino Bocaiúva canal has a drainage system incompatible with its current characteristics, $79.26 \%$ waterproofed, presenting a very low index according to the classification of Sthraler ${ }^{16}$ and that becomes susceptible to floods and floods, also observes the precarious conservation of the canals. ${ }^{13}$ The objective of the study was to analyze the precipitation in the city of Belém from 1967 to 2016, identifying the behavior of extreme events, quantity, frequency, and volume of precipitations, with monthly, annual and for decades results.

\section{Material and methods}

The city Belém, capital of the state of Pará, Brazil (Figure 1), located on the banks of Guajará Bay (lat.01 26'06”'S; long. $48^{\circ}$ $26^{\prime} 16^{\prime \prime} \mathrm{W}$ and at a distance of approximately $100 \mathrm{~km}$ from the Atlantic Ocean, is bathed by the Guamá River to the south, Guajará Bay and the Pará River to the west. Belém comprises an area of 1,059.00 $\mathrm{km}^{2}$ and has a population of 1,526,423 inhabitants according to the 2010 Census. Brazilian Institute of Geography and Statistics (IBGE, 2010). The average temperature is $26^{\circ} \mathrm{C}$, prevailing northeast wind with an average speed of $10 \mathrm{~km} / \mathrm{h}$, relative humidity of $87 \%$, was founded in 1616 and has an elevation above sea level of 16 meters. The precipitation events were analyzed with data from the National Institute of Meteorology (INMET), ${ }^{17}\left(1^{\text {st }} 49^{\prime} \mathrm{S}\right.$ and $\left.48^{\circ} 49^{\prime} \mathrm{W}\right)$ Data were grouped by day, month and year, from $01 / 01 / 1967$ to $31 / 12 / 2016$. The percentile technique was used to identify the extreme precipitations, using Equation 1 Percentile, as suggested by Xavier et al. ${ }^{18}$ Extreme events of daily rainfall were values greater than or equal to $62 \mathrm{~mm}$ for Belém and $87 \mathrm{~mm}$ for the city of Carrillo, corresponding to the ninetyninth percentile $(99 \%)$.

$$
P_{x}=\left[F_{i-1}+f_{i} \frac{X-L_{i}}{a}\right] \frac{100}{n}=\%
$$

Onde:

$\mathrm{P}_{\mathrm{x}}=$ Search Percentile

$\mathrm{L}_{\mathrm{i}}=$ Lower limit

$\mathrm{F}_{(\mathrm{i}-1)}=$ Accumulated absolute frequency above the percentage sought

$\mathrm{a}=$ Range width containing percentage

$\mathrm{f}_{\mathrm{i}}=$ Simple absolute frequency of the desired percentage range

$\mathrm{n}=$ Sample size

$\mathrm{X}=$ Percentage sought

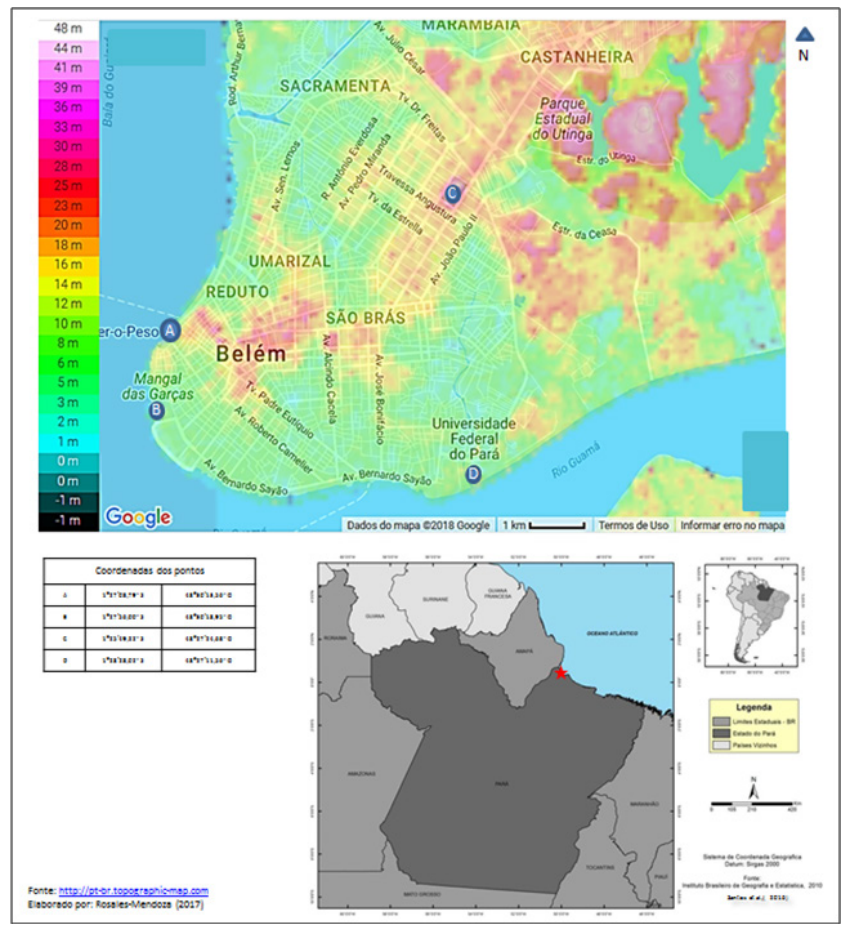

Figure I Representation of the topography of the city of Belém do Pará, Brazil.

Source: Prepared by the Author 


\section{Results and discussion}

The data reveal the highest and lowest values of precipitation in the period from January 2, 1967 to December 31, 2016, are 200.8 and $0 \mathrm{~mm}$ respectively (Figure 2). The mean value is $8.4 \mathrm{~mm}$; in the period the days that have precipitation equal to zero represent approximately $30 \%$. The analysis centered on the observation of high precipitations, therefore, it used the percentile with a k-eximo value of 0.99 to obtain the boundary line, which is $62 \mathrm{~mm}$ of precipitation. In the daily precipitation history, some spare points using the boundary line, the data were grouped again in multiples of $62 \mathrm{~mm}$, the results in Table 1. The 200 data with a precipitation equal to or greater than $62 \mathrm{~mm}$ are shown in Figure 3. The five events with the highest precipitation occurred in 1985 (136.9mm), 2000 (133.7mm), 2005 (200.8mm), $2008(131.4 \mathrm{~mm})$ and $2013(161.20 \mathrm{~mm})$, the highest being that of 2005. Identify a 15 -year distancing between the first event $136.9 \mathrm{~mm}$ in the precipitation and the second most important in the year 2000, after the period of time between 3 and 5 years, the events have a precipitation equal to or greater than $118 \mathrm{~mm}$ precipitation (Figure 4). The precipitation growth trend of the analyzed events is approximately $0.11 \%$, the annual history and growth (Figure 5). Taking as a limit the year 1967, it observed a tendency to growth until 1974, despite a fall from $3,315.3 \mathrm{~mm}$ to $1,257.4 \mathrm{~mm}$ in the year 1975 , almost immediately precipitation accumulates returns the trajectory of the growth trend with variations, but always with growth until the year 2016 (Figure 6 ), where it registers the less accumulated precipitation in the period of the 50 years, bigger than that observed in 1975, cumulative annual precipitation of $904.6 \mathrm{~mm}$. The period of intense rains begins in the month of December and extends until the month of April, decreasing in the month of May until the month of November, nevertheless the presence of rains is permanent, always has rain.

Table I Grouping by precipitation interval

\begin{tabular}{lll}
\hline Rank PRP & Number of events & Reason \\
\hline I86,0 I a 240 & I & 0,00005 I \\
I24,0 I a I86 & 4 & 0,000205 \\
62,0 I a I24 & 195 & 0,010003 \\
I,0I a 62 & II607 & $0,5954 \mid 4$ \\
0 a I & 7687 & 0,394326 \\
\hline Total dados & 19494 & \\
\hline
\end{tabular}

In the last two decades the highest concentrations of rain occurred in the month of March, draws attention because in previous decades happened in the month of February. The trend and a growth rate of $6.86 \%$ in the last five decades (Figure 7). The variation of precipitation in the city of Belém do Pará, Brazil from 2000 to 2016, the annual and average monthly cumulative precipitation, it can be verified that most of the annual precipitations were above $2000(\mathrm{~mm})$, with a tendency to increase. It is observed that the year 2003 presented lower annual precipitation of $2769(\mathrm{~mm})$ and 2013 with the highest rainfall $3776 \mathrm{~mm}$. The average of 2003 was $231 \mathrm{~mm}$ was under the influence of El Niño (EN) and La Niña (LA), while the year 2013, which was influenced by the La Niña phenomenon (LN) had the highest average precipitation of $315 \mathrm{~mm}$. The variation of the monthly average rainfall shows two periods:

a. A period of less rain that goes from May to November, with months with less rain $(<300 \mathrm{~mm})$ and

b. A period with higher rainfall with rainfall $>300 \mathrm{~mm}$, reaching $50 \mathrm{~mm}$ in the month of May, it is evident that the month of May is where the highest rainfall occurs.

The precipitations of the city of Belém do Pará evidenced the influence of the ENSO that significantly altered the meteorological variables intensifying or inhibiting the convective activities in the region. Because temperatures were high and precipitation was below average in the year of El Niño, while in the year of La Niña precipitation was above the half of the period. However, annual and interannual scale oscillations appear to determine local precipitation. Rainfall in the metropolitan region of Belém presents spatial and temporal variability. We also observe instability caused by the association to the edge of a High Level Cyclonic vortex (VCAN). ${ }^{17-24}$ So, the precipitation of the city of Belém do Pará is influenced by the large-scale Forces of Intertropical Convergence Zone (ITCZ) because the ZCIT is more to the north of the equator, in the months of July to November, when the ITCZ is further south from the equator from December to May, the rains are higher. In addition, ENOS interferes with the amount of rainfall, since in 2003 it was under the influence of El Niño (EN) and 2013 we were influenced by La Niña (LA). The calculation of percentile with k-eximo of $99 \%$ allowed separating 46 events with value above $70 \mathrm{~mm}$, it can be identified that on April 24, 2005 had the largest event with $200 \mathrm{~mm}$ of precipitation. When analyzing extreme precipitation in the city Figure 8 , it can be identified that the years 2006 and 2011(8A) had the highest concentration of extreme precipitations, in April it is the one with the highest concentration of extreme events, these high precipitations happen with some frequency between 13,15 and 29(8B). Some dates with higher pluviometric volumes coincided with local newspaper reports, ${ }^{25}$ that identified and indicated the neighborhoods of Cremação, Jurunas, Batista Campos, Pedreira, Guama, Marco and Campina such as those most affected by the heavy rains. In the case of April 24, 2005, the G1 news reported the neighborhoods Cremação, São Bras and Marco with flooded streets. ${ }^{26-32}$

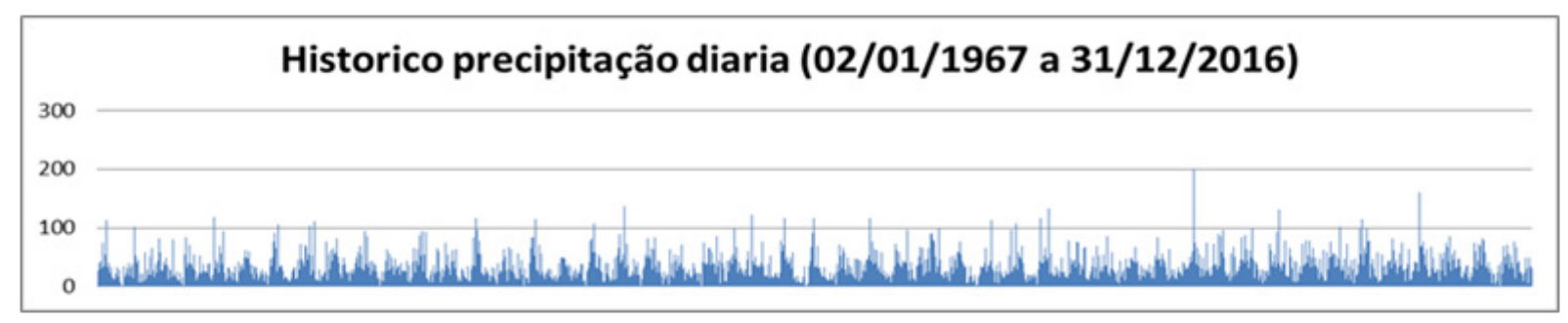

Figure 2 Historical daily precipitation.

Source:Author 


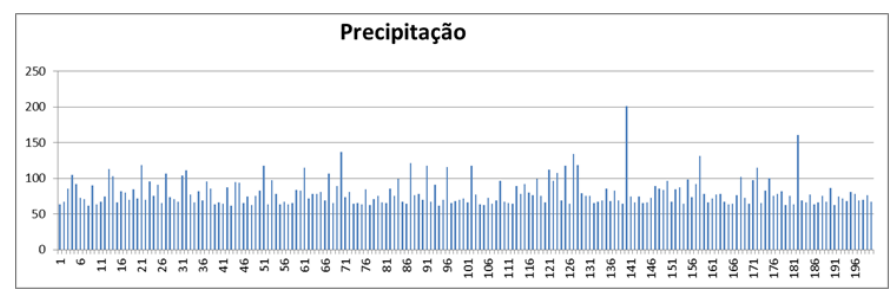

Figure 3 Extreme precipitations of the period 1967-2016.

Source:Author

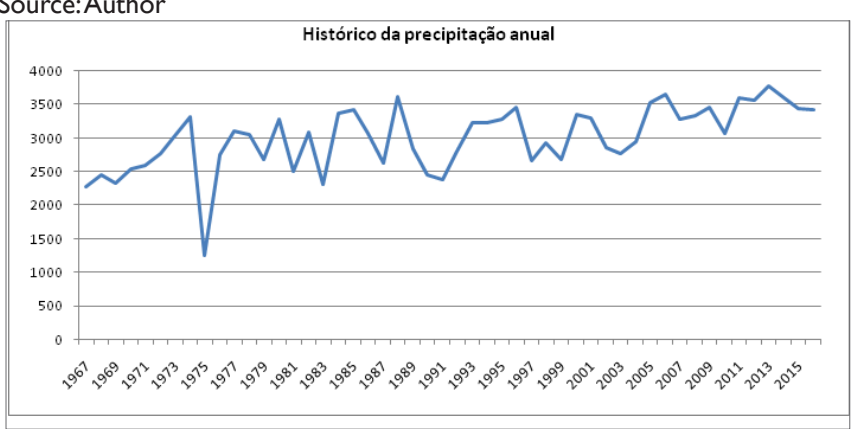

Figure 4 Periocity (A) Growth in millimeters of extreme events. (B) Comportamento das precipitações extremas.
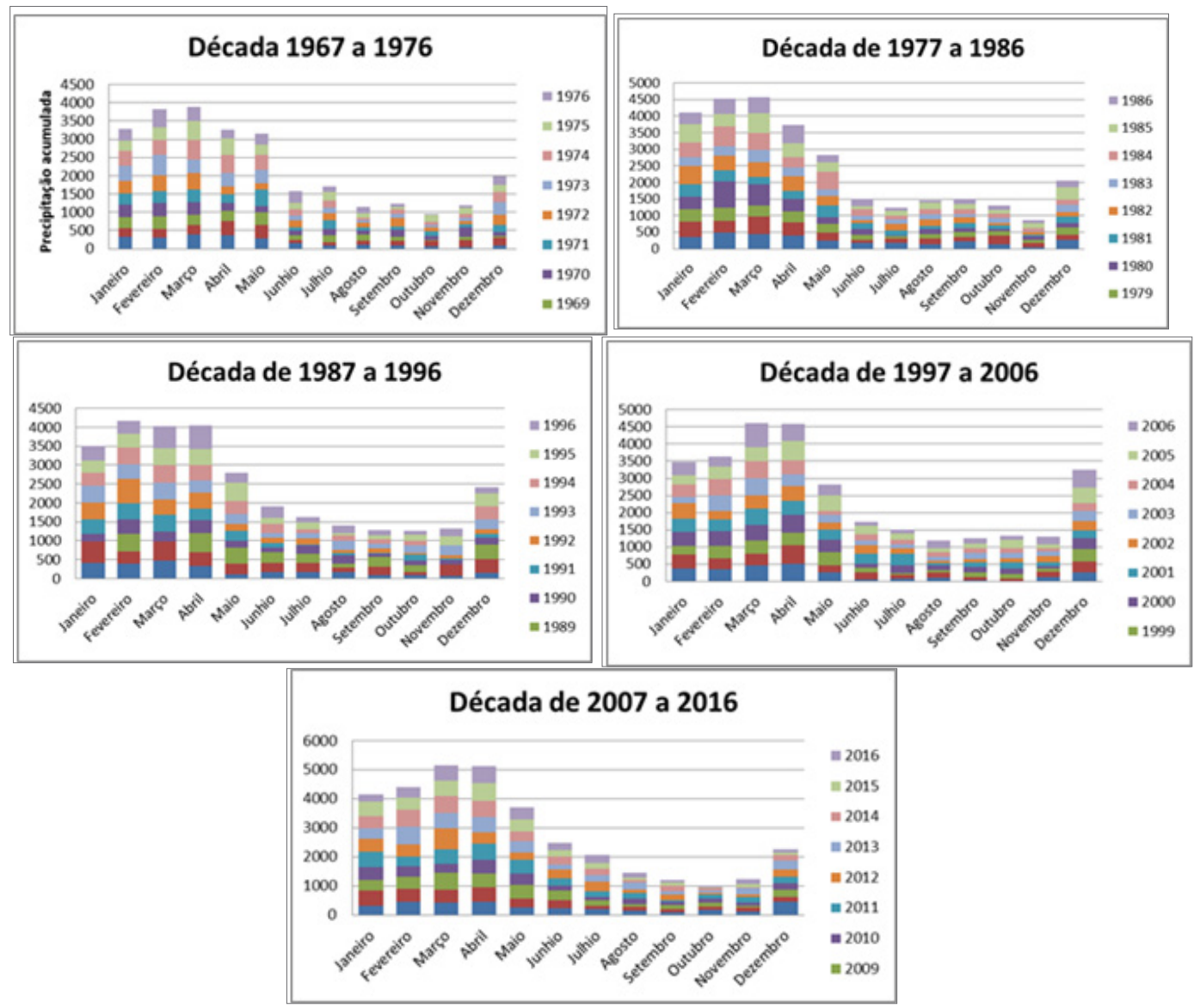

Figure 6 Histogram per decade.

Source:Author
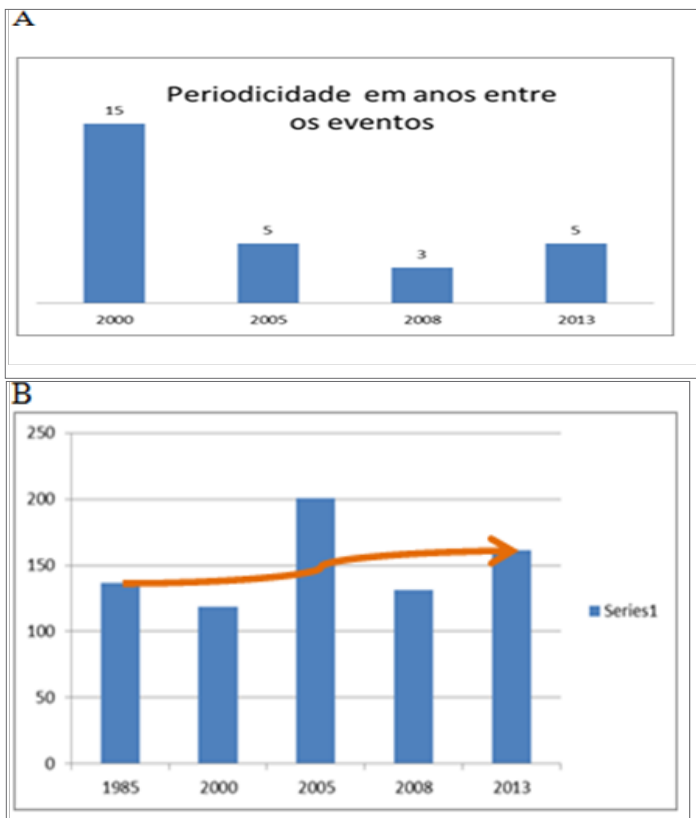

Figure 5 Histogram of precipitation in the period 1967-2016. Source:Author
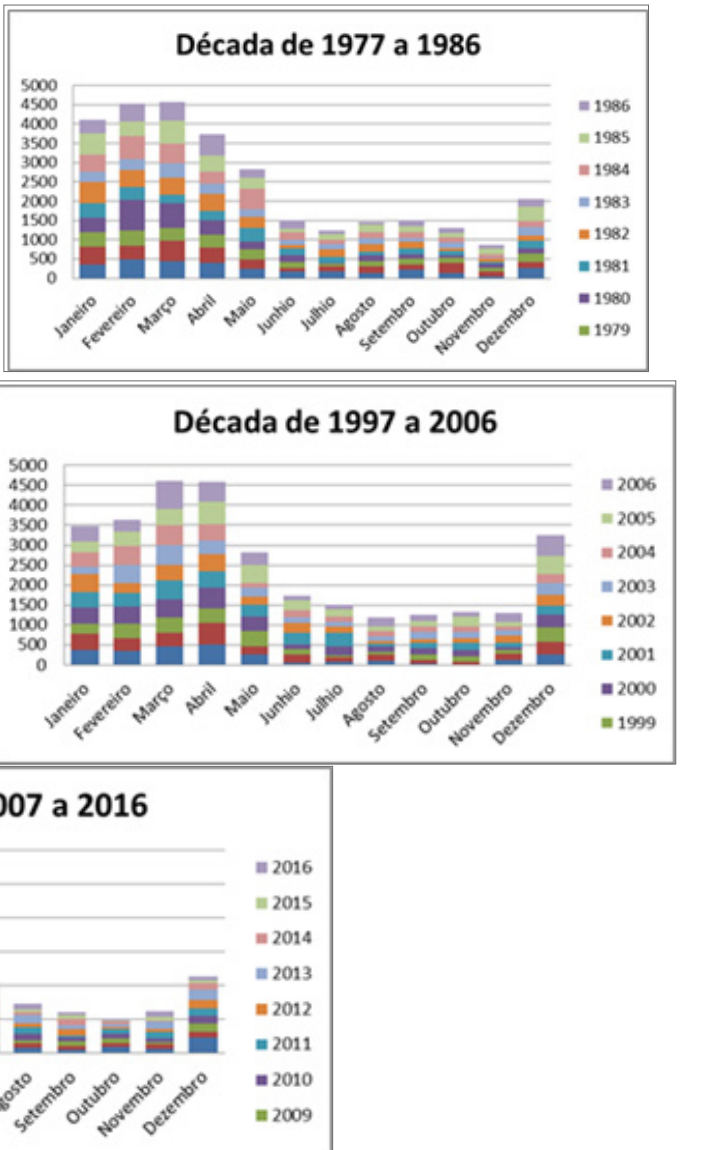


\begin{tabular}{|c|c|c|c|c|c|c|c|}
\hline \multirow{3}{*}{$\begin{array}{c}\text { Década } \\
1967 \text { a } 1976\end{array}$} & \multirow{3}{*}{$\begin{array}{r}\text { Acum PRP } \\
25339,2\end{array}$} & \multirow{2}{*}{$\begin{array}{c}\text { Taxa } \\
\text { crescimento }\end{array}$} & \multicolumn{5}{|c|}{ Precipitação por Década } \\
\hline & & & & 32650,3 & & 30684 & 32036,9 \\
\hline & & & 25399,2 & & & & \\
\hline 1977 a 1986 & 32650,3 & 0,288529235 & & & & & \\
\hline 1987 a 1996 & 29941,1 & $-0,082976267$ & & & & & \\
\hline 1997 a 2006 & 30684,3 & 0,024822067 & & & & & \\
\hline 2006 a 2016 & 32036,9 & 0,044081175 & & & & & \\
\hline Média & & 0,068614 & 1967 a 1976 & 1977 a 1986 & 1987 a 1996 & 1997 a 2006 & 2006 a 2016 \\
\hline
\end{tabular}

Figure 7 Representation per decade.

Source:Author

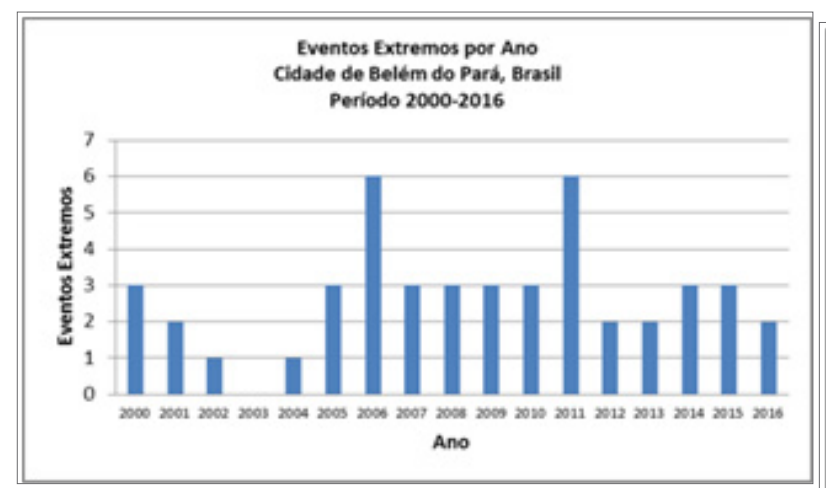

Figure 8 Extreme precipitation in the city of Belém do Pará, Brazil 2000 to 2016, (A) Extreme precipitation per year. (B) Extreme precipitation per month. Source:Author

\section{Conclusion and recommendations}

The very rainy season in the city of Belém begins in December, "very rainy" because the city has rain all year round, without dry periods, influenced, due to its location south of the equator line by the ITCZ, in addition, is also influenced by ENSO, which interferes with the amount of rainfall, as observed in 2003 was influenced by El Niño (EN) and 2013 was influenced by La Niña (LA). In the month of May and the month that presents the greatest amount of extreme events due to heavy rains, due to the fact that the previous month (April) has the highest amount of precipitation, leaving the soil saturated and favoring the conditions for floods. This natural condition that favors the phenomenon of floods and increased by the development of the population, in most cases it was observed the contempt to the urban planning, constructions in or under the protection zones / areas, as a consequence drainage, "water without cleaning administration, generating stagnant water focus of Leptospirosis. Taking advantage of the knowledge of the precipitation behavior, it is possible to send some corrective or preventive actions in the period of less rain, to minimize the impacts of the floods in the rainy season, actions to avoid the standing waters, mainly avoiding the outbreaks of diseases to the residents. Residents should also assess the suitability of staying within vulnerable areas or areas of high risk exposure, but can only make the decision if they have been informed, in a colloquial language, with certain information like the ones used in this study. In this sense, management can value the convenience of moving settlements and placing them in areas of lesser vulnerability by planning and limiting their use. Planning should also be done for areas that have become available and available for better urban management. ${ }^{33-35}$

\section{Acknowledgements}

To the Coordination of Improvement of Higher Education Personnel and to the Research Dean of the Federal University of Pará for the opportunity to carry out this study through research and funding. To INMET for making the data available. To the Organization of American States (OAS) for the invitation to participate in the Program (PAEC-CGUB).

\section{Conflict of interest}

The authors declare there is no conflict of interest.

\section{References}

1. Schubart MOR. Ecological-economic zoning and water resources management. Management of water resources and management of land use. 1997.

2. Marandola JRE, Hogam DJ. Natural hazards: the geographical study of risks and hazards. Environment \& Society. 2004;7(2):95-110.

3. Mcbean GA. Climate change and extreme weather: a bais for action. Natural Hazards. 2004;31:177-190. 
4. Lanna, Antonio Eduardo. Insertion of water management in environmenta management. In: Interfaces of Water Resources Management: challenges of the Water Law of 1997. Secretariat of Water Resources. 2000;75-108.

5. Tucci CEM, Bertoni CEM. Urban floods in South America. Dos Autores. 2003;1-44.

6. Postel S, Carpenter S. Freshwater ecosystem services. In: Daily GC, editor. Nature's Services: Societal dependence on natural ecosystems. Life Sciences. 1997;195:195-214.

7. Ryan D. Decision-making and climate change: bringing science and policy closer together in Latin America and the Caribbean. Institute of Montana. 2016.

8. Campbell-Lendrum DC, Corvalán C. Climate change and developingcountry cities: implications for environmental health and equity. Journal of Urban Health. 2007;84(1):109-117.

9. Tassara ET, De O, Rutkowski EW. Climate change and global socioenvironmental changes: reflections on future alternatives; 2008.

10. Brondizio ES, Moran EF. Human dimensions of climate change: the vulnerability of small farmers in the Amazon. Philosophical Transactions of the Royal Society B: Biological Sciences. 2008;363(1498):1803-1809.

11. NOAA/NWS/CPC. South Atlantic Thermal Index (SATL). CIIFEN 2013. 2017.

12. Ponte JPX. Belém do Pará: city and water. Cadernos Metrópole. 2015;17(33):41-60

13. Santos FAA. Urban flood and flood: an experimental model for risk assessment. 2010. 97f. Dissertation (Master in Environmental Sciences) - Graduate Program in Environmental Sciences (PPGCA), Federal University of Pará (UFPA); 2010.

14. Dossantos FAA, Rocha EJP. Flooding and flooding in urban areas case study: city of Belém. Revista Geo Amazônia. 2014;2(1):33-55.

15. Reyna A. The use of geographic information systems (GIS) in demographic analysis. Population notes. 2006.

16. Strahler AN. Quantitative analysis of watershed geomorphology. Eos transactions American Geophysical Union. 1957;38(6):913-920.

17. National Institute Of Meterology (INMET). Meteorological Database for Teaching and Research (BDMEP). INMET. 2017.

18. Xavier TM, Xavier AFS, Alves JMB. Quantiles and extreme events applications in earth and environmental sciences. Fortaleza: RDS; 2007.

19. Liebmann B, Marengo JA. Interannual variability of the rainy season and rainfall in the Brazilian Amazon basin. Journal of Climate 2001;14(22):4308-4318.
20. Ferreira DBS. Extreme events of the intertropical convergence zone on the Atlantic during the rainy season of the Eastern Amazon 2008, 65f. Dissertation (Master in Environmental Sciences) - Concentration Area: Climate Physics. 2008;1-65.

21. Moura MN, Vitorino MI. Variability of precipitation in time and space associated to the zone of intertropical convergence. Brazilian journal of meteorology. 2012;27(4):475-483.

22. Loureiro RS. Study of extreme precipitation events occurred in 2009 in the State of Pará. Brazilian journal of meteorology. 2014;29:83-94.

23. Neto AAD, Dias R. Descriptive analysis of records of evaluation of disaster damages of SEDEC. Bahian Congress of sanitary and environmental engineering. 4 Annals... AVADAN/SEDEC; 2016.

24. Oliveira FP, Oyama MD. Antecedent atmospheric conditions related to squall-line initiation over the northern coast of Brazil in July. Weather and Forecasting. 2015;30(5):1254-1264.

25. Santos MR, Vitorino MI, Pimentel MAS. Vulnerability and climate change: Socio-environmental analysis in a mesoregion of Amazonia. Environment \& Water - An Interdisciplinary Journal of Applied Science. 2007;12(5).

26. NOAA. International Center for the Investigation of the Phenomenon of the Child (CIIFEN). Oceanic Index of El Niño. 2007.

27. NOAA. South Oscillation Index (IOS). CIIFEN; 2017.

28. NOAA/NWS/CPC. Multivariable Index of the ENSO (MEI). CIIFEN; 2017.

29. NOAA/NWS/CPC. Oscillation Quase Biennial (QBO). Presure Level u: Zonal Wind Data (1950-2010); 2017.

30. NOAA/NWS/CPC. Long wave radiation (OLR). CIIFEN; 2017.

31. NOAA/NWS/CPC. Regions Child Anomaly of the SST. CIIFEN; 2017.

32. NOAA/NWS/CPC. Zonal wind. Presure Level u: Zonal Wind Data (19502010); 2017.

33. Coutinho, EC, Gutierrez LAL, Barbosa AJS. Variability of Precipitation in Belém-Pará Related to the El Niño and La Niña Phenomena. Revista Brasileira de Meteorologia. 2010;27(4):475-483.

34. National Biodiversity Authority. Climate change and biodiversity. National Biodiversity Authority. 2007;1-13.

35. Mota MAS, Oliveira MCF, Souza PFS, et al. Spatial variation of precipitation in Belém (PA) in El Niño year. III Symposium on Geographic Climatology; 1998. 